\title{
EL MISTERIO EN LAS RIMAS DE JUAN RAMÓN DESDE BÉCQUER
}

\author{
THE MYSTERY IN THE RIMAS BY JUAN RAMÓN \\ DEPARTING FROM BÉCQUER
}

Laia Olivé

Universidad de Valladolid

\section{ABSTRACT}

The Rimas by Juan Ramón pick up the thread from Bécquer's book with the same title departing from the dicotomy of the soul and the body in obvious preference for the first and rejection of the second. The mystery, what man ignores, but envisages - especially the poet—, slips through these works taking shadowy forms that belong to the spiritual and the dead. With the aim of unravelling knots knitted in them by the mystery, this article examines the two worlds that appear in both books: on the one hand, the world of the soul and death, and on the other, the world of the body and life. Further, it analyses its relation through the poet, who is appealed by the first through a «call» and whose attraction to it leads him to the «ecstasy». Finally, it treats the possible overcoming of both worlds by means of the dream.

Key words: Juan Ramón Jiménez, Gustavo Adolfo Bécquer, Rimas, mystery, dream. 


\section{RESUMEN}

Las Rimas juanramonianas retoman los hilos del libro de Bécquer con el mismo título a partir de la dicotomía alma y cuerpo en clara preferencia por la primera y rechazo hacia el segundo. El misterio, aquello que el hombre desconoce, pero entrevé — sobre todo el poeta—, se cuela en ambas obras a través de formas vagas pertenecientes a lo espiritual y a lo muerto. Con tal de desenmarañar los nudos que lo misterioso teje en ellas, este artículo indaga sobre los dos mundos que se configuran en ambos poemarios, el del alma y la muerte por un lado y el del cuerpo y la vida por el otro; se analiza su relación a través del poeta, quien siente una «llamada» del primero y cuya atracción por él lo lleva al «éxtasis»; y finalmente se trata la posible superación de ambos mundos a través del sueño.

Palabras clave: Juan Ramón Jiménez, Gustavo Adolfo Bécquer, Rimas, misterio, sueño.

Fecha de recepción: 30 de septiembre de 2020.

Fecha de aceptación: 15 de octubre de 2020.

Cómo citar: Olivé, Laia (2020), «El misterio en las Rimas de Juan Ramón desde Bécquer», en Actio Nova: Revista de Teoría de la Literatura y Literatura Comparada, 4: 547-570.

DOI: https://doi.org/10.15366/actionova2020.4.023 
Los mundos que me rodean son los que menos me extrañan;

el que me tiene asombrado es el mundo de mi alma.

Augusto Ferrán, III, en La Soledad

\section{INTRODUCCIÓN}

Los ecos de Bécquer en las Rimas de Juan Ramón Jiménez han sido escuchados e interpretados por numerosos filólogos ya desde los alrededores de su publicación ${ }^{1}$. El mismo Juan Ramón, en un afán de esclarecer su becquerianismo, señala que éste no reside en la forma, sino «en el ritmo interion», pues, si tiene «que ver con Bécquer, no es por el espíritu, sino por la clase de poesía» (Jiménez, 1990: 100). O, como señala Harter, se trata «no de una influencia sino de una confluencia» (Harter, 1960: 48). Más allá del romanticismo y del simbolismo ya latente en Bécquer ${ }^{2}$, lo que une a ambos poetas es una poesía que atraviesa las clasificaciones temporales y que constituye parte de lo clásico e imperecedero en el arte, de la poesía que Bécquer separó de la «engalanada» (Bécquer, 1970: 549) y que aparece «desnuda» en Jiménez ${ }^{3}$. Una poesía que «va por dentro», como supuestamente comentó Rubén Darío al conocer al moguereño, y que sale de ello. «Si las entrañas tuvieran su propia voz, sería con la que hablaba Bécquer», comenta este último. Las rimas becquerianas son para él «como un corazón descubierto que va a encojerse si le tocamos». Y lo que surge del alma no se acaba, al contrario de lo que es del cuerpo: «Como son entrañas del alma, las rimas viven sin descomponerse» (Jiménez, 1990: 100, 69). El interior, pues, de las obras de ambos poetas vamos a observar para tratar de desentrañar lo que en ellas reside.

Ya en el texto introductorio al libro pone Juan Ramón de manifiesto algunos puntos que nos pueden acercar más a su comprensión. Se trata de estos dos textos de Augusto Ferrán:

\footnotetext{
${ }^{1}$ Juan Ramón comenta este hecho en un aforismo (Jiménez: 1990, 100). Otras investigaciones más actuales se hallan, p. ej. en Harter (1960), Gicovate (1965), McKeever, (1967), González Dengra (1998), Urrutia (20022004), Reyes Cano (2008) o Carmona Tierno (2012).

${ }^{2}$ El simbolismo en Bécquer es notado, p. ej., por Gibert y Franch en su «Estudio preliminar» a las obras becquerianas (Bécquer, 1970: 27) o West-Settle (2005: 152). Un aporte interesante sobre el romanticismo y el modernismo en Bécquer lo brinda González Dengra (1998), quien, al igual que p. ej. Lanz (2009: 486), pone de relieve la labor de Juan Ramón recuperando al sevillano y reconociéndolo como iniciador de la poesía española contemporánea. El mismo Jiménez lo sostiene en «Dos aspectos de Bécquer»: «con Bécquer, libre y nuevo, empieza en España e Hispanoamérica la poesía moderna... y la modernista» (Jiménez, 2010: 138).

${ }^{3}$ Véase el conocido poema $\mathrm{V}$ de Eternidades en el que, como una mujer primero «vestida de inocencia» y luego «fastuosa de tesoros», aparece, finalmente, «desnuda toda» (Jiménez, 2005b: 378).
} 
-Yo no sé lo que yo tengo,

ni sé lo que me hace falta,

que siempre espero una cosa

que no sé como [sic] se llama.

-Eso que estás esperando

día y noche, y nunca viene;

eso que siempre te falta

mientras vives, es la muerte. (Jiménez, 2005a: 16; Ferrán, 1998: 63, 132)

El primero pertenece a La Soledad (XVIII), mientras que el segundo es de La Pereza (CXXXVIII). Se expresa, en el primero, el afligimiento ante una suerte de "enfermedad" del alma y su espera ante algo que necesita y no sabe cómo llamar. Es interesante cómo Jiménez complementa, o completa, los dos poemas uniéndolos, gracias a los guiones largos, en forma de diálogo. Así, el segundo constituye la respuesta a «eso que siempre [le] hace falta» al yo poético: la muerte. La vida, pues, se muestra como una apertura que provoca desasosiego y se contrapone a la muerte, que es lo que ha llegado a término; el estar uno, finalmente, cerrado y completo, sin cambio. La muerte, como señala Bécquer en su prólogo a La Soledad, es «un germen [...] dentro de nosotros mismos» (Bécquer, 1970: 555) que todavía ha de nacer. Estando vivos, la intuimos, pero no la conocemos. Si lo ignoto despierta miedo porque no sabemos cómo tratarlo (p. ej. viajar a un lugar nuevo, un animal jamás visto antes), el mayor misterio y, por ende, nuestro mayor terror, es la muerte. Ella es la que une a estos tres poetas - y a todos los hombres.

Comentando el mencionado poema, junto con otros del mismo autor, Bécquer habla de «[e]sa impaciencia nerviosa que siempre espera algo, algo que nunca llega, que no se puede pedir, porque ni aun se sabe su nombre; deseo quizá de algo divino que no está en la tierra y que presentimos, no obstante» (Bécquer, 1970: 555). Así, se separa de Ferrán al situar ese misterio fuera de nuestro mundo, en un plano «divino» y, sin embargo, «pre-sentible» desde el nuestro; es decir, apreciable antes de haberlo siquiera visto. Como veremos, este «otro» mundo, espiritual e incorpóreo, al que nombraremos «del alma y de la muerte», se entrometerá en el nuestro, el «del cuerpo y de la vida» (sección 1) e implicará al poeta por medio de la «llamada» (a través de imágenes y otras percepciones sensoriales) y el «éxtasis» (saliendo, quizás, el poeta, por unos instantes, de nuestro mundo; sección 2). Este choque entre ambos mundos se vería superado en el sueño (sección 3), donde, aún en el plano material, lo espiritual parece dejar atrás brevemente al cuerpo, cumpliéndose así el ideal platónico ostentado en los dos libros de Rimas. 
Dadas las numerosas aproximaciones al misterio y la fantasía y a su relación con la poesía en la teoría filológica, sobre todo desde las últimas décadas, creemos necesario exponer antes de proseguir nuestro tratamiento al respecto. En cuanto a la poesía, la leemos aquí como lírica, como aquello que trae a la presencia las cosas a través de la palabra. Descartamos, por ende, la ficcionalidad en ella si no es en clave de símbolo ${ }^{4}$. Respecto a la fantasía, la comprendemos no como categoría literaria, sino desde su sentido etimológico, es

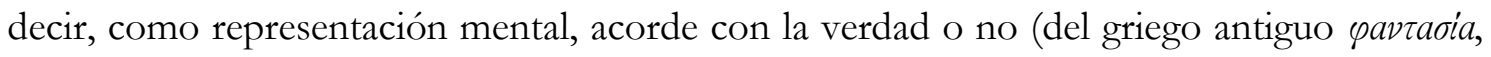
«el poder mediante el cual se representa un objeto» ${ }^{5}$ ), comúnmente en forma de imagen (palabra de origen latino que surge de la griega y que, a su vez, nos remite a la imaginación). Puesto que también es parte, si no la base, del hombre imaginar — pensar en forma de imágenes - siempre desde lo que conoce, es decir, desde la realidad, aunque pueda inventar elementos y seres que no se den en ella (p. ej. fantasmas), damos cabida a la fantasía en la poesía que, además, puede usarse como figura. No obstante, y para no incurrir en confusiones, nos decantamos aquí por el término del «misterio» para tratar aquello que, si

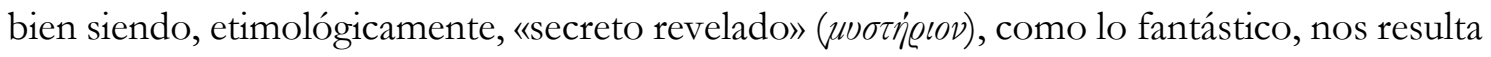
inexplicable a partir de nuestro conocimiento, porque va más allá, lo tras-ciende ${ }^{6}$.

\section{EL MUNDO DEL ALMA Y LA MUERTE Y EL MUNDO DEL CUERPO Y LA VIDA}

«Toda la naturaleza se compone, lo mismo que el hombre, de materia y de espíritu», escribe Juan Ramón en uno de sus aforismos (Jiménez, 1990: 49). Este tópico platónico se repite a lo largo de toda su Obra, y con más fuerza en la primeriza. En sus Rimas, cuerpo y alma adquieren valor, siendo el primero algo más bien superfluo e innecesario al lado de la divinidad y la pureza de la segunda, como se observa en la VIII, titulada «Noche de mayo»:

Yo estoy pensando en que hay cuerpos que sobran acá en la tierra,

\footnotetext{
4 Así, nos oponemos por un lado a Todorov, quien sitúa a la fantasía necesariamente en el plano de la ficción y la excluye de la poesía (Todorov, 2001: 66-67). Por el otro, tampoco coincidimos con Reisz, que admite la fantasía en la poesía por la ficcionalidad posible en la última considerando lo ficcional como la discordancia entre la situación de enunciación y la de escritura (Reisz, 2014: 175).

5 Véase Liddell y Scott (1996).

${ }^{6}$ Nos mostramos, pues, de acuerdo con aquellas definiciones sobre lo fantástico que hacen hincapié en su intromisión en y desestabilización de las normas de lo cotidiano, como p. ej. Todorov (2001: 29), Vax (1960: 8), Castex (1951: 8), Caillois (1975: 14-15) o Barrenechea (1972: 397). Sin embargo, y en aras de indagar en los fundamentos universales de los textos que trataremos, dejamos a un lado las posibles asociaciones sociológicas e históricas que puedan suscitar.
} 
porque sujetan las almas

cuando las almas se elevan. (Jiménez, 2005a: 25)

Lo físico impide a lo espiritual florecer en todas sus capacidades, atándolo a una tierra que no parece suya del todo ante su intento de ascender, de subir al cielo, lugar al que supuestamente pertenece. Esta distinción figura también en Bécquer, quien escribe, por ejemplo, que el alma «ambiciona un paraíso» en la Rima LVI, aunque «ignorando por qué» (Bécquer, 1970: 108). En la LXXV tenemos, por un lado, el cuerpo, «la cárcel que habita [...] el espíritu», «la humana forma»y, por el otro, una «región vacía», el «mundo silencioso»y «de visiones» que el sevillano no sabe si «vive fuera o va dentro de nosotros» (Bécquer, 1970: 122), si bien en la LXXI lo sitúa en nuestro interior?

Admiten ambos poetas la existencia de un mundo del alma y de los muertos (ya liberados del cuerpo) que se encuentra en la nada y donde, para Bécquer, como en Platón, habitan las ideas sin forma y que, por lo tanto, no se puede describir; y un mundo del cuerpo (aunque con alma) y de la vida que les es insuficiente porque no les permite completarse espiritualmente. Esto aflige a ambos poetas, cuyas almas parecen estar "enfermas" desconociendo el motivo, como en la Rima LXX juanramoniana, titulada «Solo», en la que el yo poético está «malo, muy malo», sin saber de qué (Jiménez, 2005a: 98-99). El yo lírico becqueriano también se encuentra «[c]ansado del combate / en que luchando viv[e]», como remarca la $\mathrm{LXXVI}^{8}$. Parece estar buscando algo, ignorando el qué, como en el primer fragmento de Ferrán. En su Rima VIII, siguiendo lo visto en nuestra introducción, siente que «estas ansias [le] dicen / que [él] llev[a] algo / divino aquí dentro». Explicita en la LXXXII que eso que persigue «[e]rrante por el mundo» es la gloria, hasta que «una voz misteriosa» le responde que está «más allá..., más allá...». Pero, al encontrarla, se convierte en humo que va al cielo ${ }^{9}$. No se trata de una gloria por reconocimiento de otros, sino de una tranquilidad; como menciona la LXXII, una «isla de sueños donde reposa / el alma ansiosa» (Bécquer, 1970: 123, 84, 117). En Juan Ramón, incluso, algunos niños mueren sonriendo y hay muertos

\footnotetext{
${ }^{7}$ «[M]as otra luz el mundo de visiones / alumbraba por dentro» (Bécquer, 1970: 116).

${ }^{8}$ No obstante, el poeta menciona en su «Introducción sinfónica» a las Rimas que su lucha se debe a «los extravagantes hijos de [su] fantasía» que le persiguen para que les de forma con su palabra (Bécquer, 1970: 7374). Jiménez también menciona este hecho: «Mi trajedia es este afán de hacer permanente todo lo fugaz, renovando cada día el imposible de entrar en doce horas de reló todo mi universo íntimo» (Jiménez, 1990: 287), pero, dado que no lo hace explícitamente en sus Rimas, lo descartamos como punto de unión en nuestro análisis. ${ }^{9}$ La edición citada no incluye esta rima, pero sí la de Afrodisio Aguado (Bécquer, 1950: 130).
} 
que sonríen ${ }^{10}$, como complacidos al haber alcanzado el cielo, que es «la realidad mayor de nuestro idilio» en la Rima V, «En medio del verano» ${ }^{11}$; «la azul lejanía / en que anhela [su] vida vivir» en la LVI, «En la aurora». En la LXI del mismo, el yo poético contempla el cenit y ve que «allá lejos, muy lejos, está [su] alegría, / en los [suyos] clavando sus lívidos ojos» (Jiménez, 2005a: 107, 85, 89). Estando en otro plano su dicha, no puede sino sentirse acongojado en este mundo, ansiando el otro, lo que le conduce a una lucha constante consigo mismo que acarrea soledad y dolor.

La tristeza tiñe ambos libros de rimas y crea un tono particular confundiéndose, a menudo, con la alegría ${ }^{12}$. El dolor mora en la vida humana - «padecer es vivir» escribe Bécquer en la LVI (Bécquer, 1970: 108)—y puede, incluso, desembocar en la dicha. La Rima juanramoniana LXIV, «Inefable», sostiene «que el alma florece cuando anhela martirios, / cuando amante y rendida se somete al dolor» y así «se eleva al azul delirante de amor» (Jiménez, 2005a: 94), es decir, al cielo. Lo mismo se encuentra en Bécquer, quien escribe que «si grande el martirio, / mayor el premio» en la LXXXV ${ }^{13}$. Cossío, en su reflexión sobre la Rima IV becqueriana, sitúa estos elementos en lo que él llama el «mundo del sentimiento» por contraposición al «de lo sensible» y al «del misterio» y donde se encontraría la discordancia entre mente y corazón (Cossío, 1936: 321-325). Sin embargo, más que un mundo, nosotros consideramos estos aspectos como una manera de estar en el mundo del cuerpo y de la vida ${ }^{14}$. Así, en la LXVI, «A mis penas», el yo lírico juanramoniano llama a sus penas «adoradas salvadoras / del perfume de [su] vida» (Jiménez: 2005a: 96).

No obstante, no es solamente esta lucha lo que arrastra a la desdicha, sino también la aparición de la muerte en el mundo de la vida a través del cuerpo sin vida, solo y triste. Esto muestra la Rima LXXIII becqueriana:

¿Todo es sin espíritu

podredumbre y cieno?

¡No sé; pero hay algo que explicar no puedo,

${ }^{10}$ P. ej. en la XV («cayó muerta la niña / sonriendo, sonriendo»); la XXX, «iSilencio!» («[m]urió riendo el niño»); o la LX, «Versos de niños» (la «boquita» de la niña muerta «sonreía / con una sonrisa plácida») (Jiménez, 2005a: $34,56,87)$.

${ }^{11}$ En el apéndice de la edición citada.

${ }^{12}$ En la LV, el yo lírico becqueriano tiene «alegre la tristeza»; y en el amor, «lo cómico y lo grave, confundidos, / risas y llanto arrastran», dice la XXXI (Bécquer, 1970: 108, 96).

${ }^{13}$ La edición citada no incluye esta rima, pero sí la de Afrodisio Aguado (Bécquer, 1950: 133).

${ }^{14}$ Nos acercamos más a la conjunción que hace Pedro Díaz de lo real con lo fantástico en el mismo plano, si bien él los sitúa en un mismo mundo: «Ese mundo, en el que se entrelazan formas de lo real, de lo intuido y de lo soñado, constituye de manera esencial la poesía de Bécquen». Más adelante, sin embargo, sí distingue entre dos regiones: una donde habita lo vivo con turbadas presencias, y un más allá, «un más profundo pliegue de la vida» (Pedro Díaz, 1964: 377, 434). 
algo que repugna

aunque es fuerza hacerlo

a dejar tan tristes [sic]

tan solos los muertos! (Bécquer, 1970: 120)

Lo mismo aparece en Juan Ramón ${ }^{15}$, lo cual lleva al yo poético de ambos a padecer. Sin embargo, éste reconoce también que, como vivo, tiene que hacerlo para seguir viviendo.

Hay, en los poemas mencionados, cierta nota temblorosa de miedo provocado por la muerte que, manifestándose a través de los demás, da cuenta del tiempo que pasa, de lo que quita de la vida y ya no devuelve y, sobre todo, de la muerte propia, que puede llegar en cualquier momento $^{16}$. Por rehuirla, entonces, se tiende a olvidar a los muertos ${ }^{17}$. Y cuando no se logra, mientras que el poeta se lamenta de ello, los demás vivos se burlan ${ }^{18}$ o desprecian los cuerpos sin vida ${ }^{19}$. Así, tratando éstos de escapar de la propia condición de mortal agarrándose a la vida y sus cosas, el poeta, por su deseo de trascender lo corpóreo y quizás también por temor a lo desconocido, experimenta a la vez un sentimiento opuesto: una atracción hacia ella. Ésta puede convertirse en un deseo propio de $\operatorname{morir}^{20}$ o tomar la forma de otro ser atrayente, de una mujer inalcanzable, como muestra la conocida Rima XI de Bécquer, en la que se expresan preferencias por un ser vago y de otro mundo ante las mujeres del nuestro:

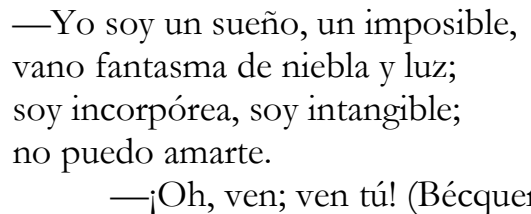

$$
\text { —iOh, ven; ven tú! (Bécquer, 1970: 85) }
$$

A pesar de tratarse de un amor no correspondido, pues ese ser es incapaz de amar, el yo poético becqueriano no lo cuestiona como su ideal, ya que pertenece al mundo que él tanto

\footnotetext{
${ }^{15}$ P. ej. en la Rima XLI, «Aromas y lágrimas» (una niña muerta «solita fue al camposanto») o en la LXV (el yo poético recuerda a «[su] muerta», que «jestá la pobre tan sola, / tan sola en el cementerio!») (Jiménez, 2005a: 69, 94).

${ }^{16}$ El mismo Bécquer lo menciona en su introducción a las Rimas: «de una hora a otra puede desligarse el espíritu de la materia para remontarse a regiones más puras» (Bécquer, 1970: 75).

${ }_{17}$ P. ej. en la Rima LXVI de Bécquer («donde habite el olvido, / allí estará mi tumba») (Bécquer, 1970: 113) o en las juanramonianas XLI (aparece «una nítida tumba olvidada»), la XLIV, «Muerta» («la tumba de las cosas olvidadas / guarda en su fondo su podrido cuerpo») o la LIV, «El invierno» («QQué tristes son los sepulcros / en que la mano del tiempo / borró el nombre, ya olvidado, de sus muertos!...») (Jiménez, 2005a: 70, 73, 83).

${ }^{18}$ P. ej. en la LIV juanramoniana («Qué tristes, qué tristes son / esos sepulcros ya viejos / ante los que pasan todos / sonriendo») (Jiménez, 2005a: 83).

${ }^{19}$ P. ej. en la XLVIII («al cruzar por el bosque, los viajeros, / una noche de miedos y terrores, / [...] aplastarían [sus] calaveras») (Jiménez, 2005a: 77).

${ }^{20}$ P. ej. en la Rima XXXVII juanramoniana, «Tristeza primaveral» («iYo quiero morirme! / ¡Yo quiero ir contigo, alma de mi alma!») (Jiménez, 2005a: 65).
} 
ansía. Por el contrario, en Jiménez aparecen dudas. Pese a la admiración que siente hacia «los mudos fantasmas blancos / que pasan el mundo muertos», como dice la Rima XXIX, y de que «[sus] amores son vagos amores / que no encuentran aquí su placer», como canta la LVI, «En la aurora», cuando su amada pone en cuestión sus sentimientos en la LXII y expresa que él «quisiera[...] / el cariño de algún ser extraño, / de algún ser de otro mundo», no contesta con firmeza a la pregunta:

- ¿Y si yo me muero? — dijo sonriendo, sonriendo con un dejo amargo-; y si yo me muero, ¿podré ser tu ideal adorado?

—No sé —respond[ió]le. (Jiménez, 2005a: 55, 85, 91)

Quedémonos, por ahora, con esta duda, a la que volveremos para dar cierre a las Rimas juanramonianas y al presente artículo.

\section{LA RELACIÓN ENTRE LOS DOS MUNDOS (LA LLAMADA Y EL ÉXTASIS)}

El poeta se halla entre dos mundos: habita el de la vida y ansía el del alma. Así, establece una relación de "amor" recíproco, parecida a la de los místicos, con el segundo, pues ese mundo lo desea a él —y «llama»—y es deseado a su vez por él —lo cual lo conducirá al «éxtasis»—. Observemos ambas partes en Juan Ramón, teniendo en cuenta también a Bécquer.

Se ha estudiado anteriormente cómo el poeta se da cuenta de lo muerto a través del cuerpo muerto, ya sin alma. Así en (1) los muertos mismos, cuya soledad y tristeza siente y padece el poeta. Surge, asimismo, la muerte entre los vivos a través de (2) los moribundos y los que acaban de morir ${ }^{21}$. O también, junto con la pureza del alma, mediante los seres que parecen más alma que cuerpo, esto es, (3) los niños y las vírgenes, que no han sido "corrompidos" deben extrañarnos las comparaciones de los niños con otros seres y elementos de la

\footnotetext{
${ }^{21}$ P. ej. en la Rima XXVI juanramoniana, «Crepúsculo de abril» (una enferma muere y queda «muda, soñando lejanías fantásticas / y misterios floridos y alboradas quiméricas») (Jiménez, 2005a: 50).

${ }^{22}$ En la XIII del mismo, «Primavera y sentimiento», los niños son «[a]lmas / de oro» (Jiménez, 2005a: 32).
} 
naturaleza relacionados con lo puro, como los pájaros ${ }^{23}$ o las mariposas y las flores ${ }^{24}$, al igual que las niñas ${ }^{25}$, quienes embriagan al yo lírico. Él, ante su muerte, no puede hacer más que dar su «beso mejor de poeta» en la XXVII. Al igual que en los pájaros, las mariposas y las flores, lo que más caracteriza la pureza de los niños es precisamente el hecho de no darse cuenta de ella, pues hacerlo conllevaría entenderla a ésta y a su opuesta, la maldad, y abrir la posibilidad de caer en la última. «Ellas son, sin saberlo, la vida», escribe Juan Ramón sobre las niñas (Jiménez, 2005a: 52-53, 52). Lo mismo puede aplicarse a las vírgenes vivas, enfermas y muertas quienes, representando al alma casi sin cuerpo $^{26}$, vinculan los dos mundos. En Jiménez, además, lo virginal se empareja con lo divino ${ }^{27}$.

Hasta aquí, la muerte se ha manifestado en lo cotidiano, en lo que todos los vivos podemos ver. El poeta, sin embargo, no solamente dispone de una aguda sensibilidad para apreciar la muerte en este ámbito, sino también en lo extraordinario. Es capaz de percibir seres pertenecientes al cielo: (4) ángeles, la Virgen María y Cristo, quienes se vinculan en las Rimas juanramonianas a menudo con la muerte, la soledad y el dolor, y parecen tomar vida ${ }^{28}$. Los ángeles, por su lado, constituyen el punto de unión entre lo extraordinario religioso y lo cotidiano abriendo el cielo ${ }^{29}$, llevando allí a los niños muertos $^{30}$ e incluso siendo los niños muertos como ellos ${ }^{31}$.

Existen otros seres no pertenecientes al mundo de los vivos y que, a pesar de ello, surgen en él en el plano de lo extraordinario, tomando forma de (5) apariciones ante el poeta que se asemejan a las de un fantasma, es decir, a las de la imagen de un muerto. Para comprender el significado de esta palabra hace falta remitirnos a su origen del griego antiguo

\footnotetext{
${ }^{23}$ P. ej. en la misma («y los niños y los pájaros / jugarán dichosos»), en la XXXVI, «Tarde de aldea» («los niños vuelven gozosos / cual pájaros») o en la XXXVII, «Tristeza primaveral» («y cantan los pájaros y cantan los niños») (Jiménez, 2005a: 32, 61, 64-65).

${ }^{24}$ P. ej. en la XLIII, «Cuento» (el niño tiene «alma de azucena») o en la LX, «Versos de niños» («las manitas de los niños / sobre aquella tela blanca / eran flores entre hielo, / ¡mariposas sobre escarcha!») (Jiménez, 2005a: $73,88)$.

${ }^{25}$ P. ej. en la XXVII, «Las niñas» («iQue florezcan las niñas!», «Unas niñas creyéranse lirios» y «son almas de rosas») o en la XLIX, «La víspera» («las muchachas, tan frescas como flores») (Jiménez, 2005a: 51-53, 77).

${ }^{26}$ P. ej. en la Rima LX juanramoniana (una virgen muerta reposa «las manos sobre el pecho / como las tienen las santas») (Jiménez, 2005a: 87) o en la XIX becqueriana (una mujer se parece a «una azucena tronchada», y Dios le dio la pureza) (Bécquer, 1970: 90).

${ }^{27}$ P. ej. en la XXXIV, «Alborada ideal» (los ángeles son «como vírgenes blancas») o en la XXXV, «Vidriera» (Cristo está «soñando con almas virginales») (Jiménez, 2005a: 60, 61).

${ }^{28}$ P. ej. la virgen en la LXX y Cristo en la XXXV (Jiménez, 2005a: 99, 61).

${ }^{29}$ P. ej. en la Rima LXXIV de Bécquer (sus miradas parecen decirle al yo lírico que «El umbral de esta puerta, / sólo Dios lo traspasa») (Bécquer, 1970: 121) o en la XXIV juanramoniana, «El castillo» (envuelven «entre gasas los valles» y empiezan «a abrir esas estrellas / que alumbran la agonía de los cielos») (Jiménez, 2005a: 44). 30 P. ej. en las Rimas juanramonianas XLI y XXX, «iSilencio!» (Jiménez, 2005a: 67-70, 56-57).

31 P. ej. en la LIV, «El invierno» («iNiños blondos, / que abandonaron sus cuerpos / para volar; hechos ángeles [...]!») (Jiménez, 2005a: 84).
} 


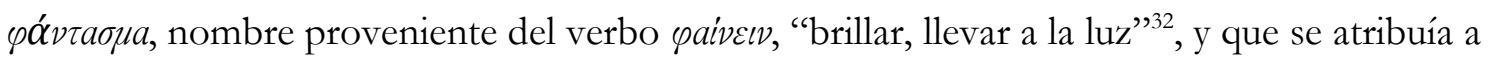
los muertos, quienes habitan el inframundo, desprovistos ya de cuerpo, como se describe en La Odisea: «no tienen los tendones cogidos ya allí su esqueleto y sus carnes, ya que todo desecho quedó por la fuerza ardorosa e implacable del fuego, al perderse el aliento en los miembros; sólo el alma, escapando a manera de sueño, revuela por un lado y por otro» (Homero, 1993: $271)^{33}$. El fantasma es aquí una proyección vaga sin profundidad y, por lo tanto, perceptible, pero inasible por los cuerpos vivos. Así, cuando Odiseo, en su viaje por el Hades, encuentra a su madre e intenta abrazarla, se le va «a manera de ensueño o sombra, [se] escap[a] de [su]s brazos» (Homero, 1993: 270) ${ }^{34}$. Al igual que los fantasmas descritos por Homero, los que aparecen en Juan Ramón y Bécquer se asemejan a un sueño y se mueven entre las sombras ${ }^{35}$ siendo elementos ambiguos, como paisajes poco claros ante los ojos. En este punto, mostramos discrepancia con West-Settle, quien trata a las imágenes y los colores en Bécquer como propios del mundo físico y atribuye al mundo espiritual sólo los sonidos y la música, pues lo perteneciente al segundo mundo aparece en el primero también a través de lo visual (West-Settle, 2005: 166).

En la Rima XV de Bécquer, el yo poético va tras el Tú que es una «onda de luz», corriendo «incansable [...] y demente / tras una sombra, tras la hija ardiente / de una visión» sin poder nunca alcanzarla, pues cuando va a tocar esa «sombra aérea», ésta «[s]e desvanece[...]» (Bécquer, 1970: 88). El cuerpo falla al querer agarrar lo que sólo es alma. Entonces, ¿‘cómo lo puede ver? Juan Ramón deja claro en la XXIV que no son los ojos del cuerpo, sino los del alma, los que pueden percibirlo:

(Hay almas que no ven, como hay pupilas

para las que los soles son engendros.

Yo amo a los soñadores cuyas almas

tienen sus ojos a la nada abiertos,

esperando que pasen las quimeras

para brindarles vida y sentimiento.) (Jiménez, 2005a: 45)

Estas visiones se encuentran en la nada y necesitan de los vivos para tomar «vida y sentimiento», ya que están muertas. Y son los soñadores, los artistas verdaderos quienes

\footnotetext{
32 Véase Liddell y Scott (1996).

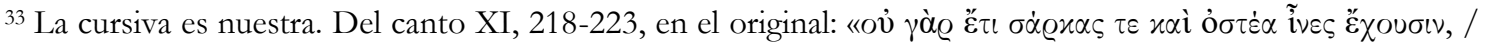

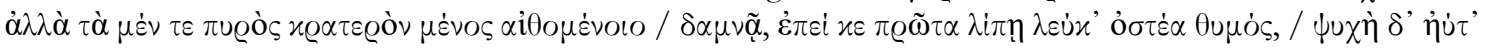

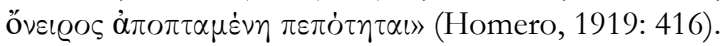

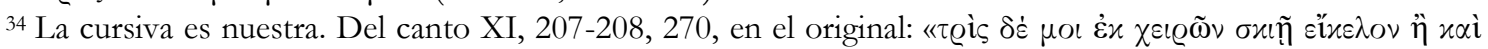

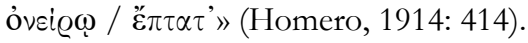

${ }_{35}$ P. ej. en la Rima XXVIII de Bécquer (la voz que surge «entre la sombra oscura») (Bécquer, 1970: 94) o la XXIV juanramoniana (se adivina «el secreto / lejano de lo envuelto entre las sombras») (Jiménez: 2005a: 45).
} 
pueden dársela, los que ven más allá de lo puramente físico para «interpreta [r] el espíritu»y «da $[\mathrm{r}]$ forma a una cosa que no la tiene», como escribe Juan Ramón en el aforismo citado anteriormente. En el mismo, a semejanza con los dos tipos de poesía expuestos por Bécquer anteriormente, Jiménez contrapone al «verdadero soñadon» con el artista «superficial y realista» que «interpreta la materia» (Jiménez, 1990: 49).

El mundo de los muertos, entonces, se cuela en el de los vivos mediante las apariciones fantasmales que los poetas — o soñadores - observan en la naturaleza e incluso a veces en ellos mismos. Estas visiones, o mejor, percepciones de los muertos y lo muerto (a través de imágenes en su mayor parte humanas y femeninas, pero también de perfumes y sonidos), sin embargo, no son hallados casualmente por el poeta, sino que ellas lo llaman a él:

Como ensueño de bruma, al través de una rama, una sombra adorada ligera se mueve; una pálida sombra de lirios y nieve, que sus labios me ofrece y gimiendo me llama. (Jiménez, 2005a: 89)

Nos dice, por ejemplo, la Rima LXI juanramoniana, en la que resuena la LXXIV de Bécquer:

La vi como la imagen, que en leve sueño pasa, como rayo de luz, tenue y difuso, que entre tiniebla nada.

Me sentí de un ardiente deseo llena el alma; ¡como atrae un abismo, aquel misterio hacia sí me arrastraba!

No en vano titula Jiménez «Visión» a su rima, haciendo así mención a esta imagen que se le aparece en su camino al cementerio y que recuerda a una mujer —igual o más claro todavía en Bécquer, quien dice que «la vi[o], confusa y blanca» (Bécquer, 1970: 121). También los muertos llaman al yo poético juanramoniano en la LXVIII (Jiménez, 2005a: 97), así como «una voz delgada y triste» atrae al becqueriano en la LXXI mientras se adormece (Bécquer, 2005: 116).

El sevillano deja clara tanto en sus Rimas como en las Cartas literarias a una mujer la relación entre la poesía y el misterio. Es la primera un «misterioso santuario» encargada de revelar «los fenómenos del alma, el secreto de la vida», una «vaga aspiración a lo bello», dice la primera carta; una «aspiración melancólica y vaga que agita [el] espíritu con el deseo de una 
perfección imposible», la tercera (Bécquer, 1980: 533-534, 540). Un anhelo de alcanzar lo inalcanzable, de desvelar el misterio que encubre la vida y la muerte y, así, trascenderlas: esto es la poesía. Como nota Guillén en su artículo sobre la poética de Bécquer, es ella «quien guía al poeta hasta los fines superiores» (Guillén, 1942: 2), o Alonso, estudiando también a este poeta, sostiene que «nos descubre hasta profundidades últimas» (Alonso, 1952: 11). El poeta verdadero, por ende, se convierte en su mediador, pues, en consonancia con las palabras de Juan Ramón, afirma Bécquer en la primera carta que «para revelarla necesita darle una forma». Así también en sus Rimas, el poeta se presenta como «ansia perpetua de algo mejor» en la XV, que sufre «la sed de lo infinito» en la LXXVI (Bécquer, 1970: 533-534, 88, 123), las ansias de superación del cuerpo y, por tanto, de la muerte; hilo que retomará Jiménez para coser con él no sólo las Rimas, sino toda su Obra, como bien observa Blanc al apelar a un «mundo poético trascendente logrado en las Rimas de Bécquer [que] continúa en las poesías de Juan Ramón» (Blanc, 1988: 14).

Para llegar a esa trascendencia, a ese estado en el que el sufrimiento causado por el vivir queda superado, el yo lírico juanramoniano desea fundirse con lo vago:

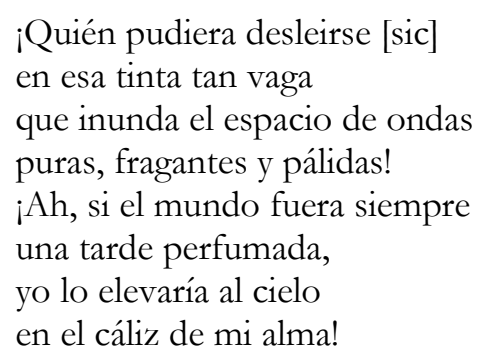

Nos dice la Rima XIII. O en la VIII, afirma que «[d]esde el cielo hasta [su] frente / hay una mística senda» (Jiménez, 2005a: 32, 25). Sirvan estos ejemplos para mostrar nuestra discrepancia con Harter, quien atribuye «una especie de misticismo poético» sólo a Bécquer, y a Juan Ramón más pragmatismo «en su persecución de la belleza» (Harter, 1960: 53). No debemos olvidar lo que la etimología de la palabra "místico" nos desvela, pues proviene ésta del griego antiguo $\mu \nu \sigma \tau \varkappa \varkappa_{\varsigma}$ y significa “conectado con los misterios", lo cual nos devuelve

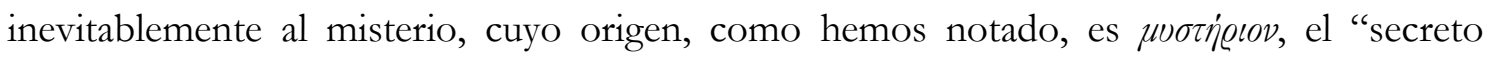
revelado" ${ }^{36}$. Así, igual que en una relación mística, el poeta se une al misterio, ama y es amado por él, que lo llama, y cuando va a él llega, como se expresa en la Rima LXII, al

$[\ldots]$ éxtasis lento, en que el alma suspendida mira[...] a lo lejos, algo ignoto, algo raro,

36 Véase Liddell y Scott (1996). 
algo así como un alma de niebla

que vaga $[\ldots]$ flotando $[\ldots]$

algo así como un cuerpo de bruma

que vaga $[. .$.$] cantando$

la canción de un amor eternal [...]. (Jiménez, 2005a: 90-91)

Mirando el cielo de día, el yo poético becqueriano también alcanzaría un éxtasis, por ejemplo, en la VIII, donde «[l]e parece posible arrancar[s]e / del mísero suelo / y flotar con la niebla dorada». Y también de noche, observando las estrellas,

[l] parece posible a do brillan

subir en un vuelo

y anegar[s]e en su luz, y con ellas,

en lumbre encendido,

fundir[s]e en un beso. (Bécquer, 1970: 83-84)

No obstante, para este poeta no basta nuestro lenguaje para captar el misterio, pues «no hay cifra / capaz de encerrarlo», se anuncia en la I (Bécquer, 1970: 76). El yo lírico juanramoniano, sin embargo, percibe el lenguaje de lo inefable, pero no lo entiende ${ }^{37}$.

El deseo de y la unión con lo divino, lo que sólo es alma, pueden hacer que el yo poético, a veces, se perciba a sí mismo como un fantasma. Parece tomar una forma vaga y aparecer ante su amada, como en la Rima V de Jiménez, «Llanto», en la que se "aleja” hasta su amada, quien lo cree «una quimera» (Jiménez, 2005a: 22). Y lo mismo en la XVI becqueriana, quien le hace saber que, «aunque invisible, al lado suyo / respir[a él]» (Bécquer, 1970: 89) ${ }^{38}$. El yo lírico juanramoniano, por su lado, también se observa a sí mismo, a veces, como un muerto. Cuando se mira al espejo en la LII «[le] parece que es la sombra / de alguien que [le] va siguiendo»y, al toparse con sus ojos, éstos le recuerdan «la fijeza de los muertos», lo que le hace sentir miedo de sí mismo. Sin embargo, este terror se resuelve con un beso (Jiménez, 2005a: 80) ${ }^{39}$. Podría este gesto interpretarse como autocomplacencia o vanagloria, pero nuestra hipótesis es otra. El beso simboliza la unión, a través de los cuerpos —las bocas—, del alma —el aliento—. Así, al verse como un muerto, el yo poético juanramoniano busca unir, o más bien, re-unir su cuerpo con su alma, lo muerto o lo que va a morir con lo

\footnotetext{
${ }^{37}$ P. ej. en la Rima XIII (las estrellas «[l]e hablan; / pero como están tan lejos, / no comprend[e] sus palabras») (Jiménez, 2005a: 32).

${ }^{38}$ También en la Rima LXXXVI o en la LXXXVIII («por un ignorado movible sendero, / ansioso de calma, / sediento de amores, penetro en tu alma») (Bécquer, 1970: 127, 129).

${ }^{39}$ Parecida a esta Rima es la XXXVIII (el yo poético, «siempre triste y solo / con [sus] penas y [sus] versos», al verse en el espejo «[se] embriag[a] de besos») (Jiménez, 2005a: 65) y la LXXXIX de Bécquer (una mujer, «la visión pura», se da un beso tras mirarse en el espejo sonriendo «a su imagen lánguida») (Bécquer, 1970: 130)
} 
vivo: la forma con su ideal ${ }^{40}$. Se dan en los dos libros de Rimas, aparte de entre seres vivos, besos entre vivos y muertos ${ }^{41}$, entre seres pertenecientes a lo extraordinario y los que acaban de morir ${ }^{42}$ o los mismos muertos ${ }^{43}$, que resuelven por un breve instante la separación entre los dos mundos ${ }^{44}$. Pero no bastan. Una conjunción más duradera habrá que encontrarla en otro plano accesible desde el mundo de la vida, de camino al cual, «limbo / en que cambian de forma los objetos» según Bécquer en la citada Rima LXXI (Bécquer, 1970: 116), las visiones se pronuncien con más intensidad hasta llegar a ser parte de la realidad en la que uno se encuentra. Hablamos del sueño.

\section{LA SUPERACIÓN DE LOS DOS MUNDOS (EL SUEÑO)}

Hemos visto que el mismo Juan Ramón empareja, por ser mediador entre el mundo de la vida y el de la muerte, la figura del poeta verdadero con la del soñador ${ }^{45}$. Así como el místico al misterio y el poeta a la poesía, el soñador se vincula al sueño, en el cual se dan las mismas normas que en el mundo de la vigilia, pero con la posibilidad de alterarlas. «Los sueños son el espíritu de la realidad con las formas de la mentira», apunta Bécquer en su Leyenda «El caudillo de las manos rojas». El tiempo puede transcurrir de modo distinto, y el espacio cambiar de un momento a otro. Y, a menudo, cuando se vuelve del sueño, uno no lo recuerda o no puede explicarlo todo, como se le pregunta a la mujer en la segunda Carta literaria becqueriana: «¿No has soñado nunca? Al despertar, ¿te ha sido alguna vez posible referir, con toda su inexplicable vaguedad y poesía, lo que has soñado?»> ${ }^{46}$. En sus Cartas desde mi celda, Bécquer afirma también que, tras haberse debatido entre la vigilia y el sueño, «sólo

\footnotetext{
40 Interesante es también lo que comenta sobre Narciso Juan Ramón: «Narciso es el hombre superior, el "hombre difícil" enamorado no de sí mismo, ni mucho menos del hombre, de su propio hombre, del otro hombre, sino de la mujer ideal que todo hombre superior lleva física y moralmente, espiritualmente dentro de su propio ser» o «Narciso es el amor, la paz, el fin humano, fin igual a su principio» (Jiménez, 1990: 484, 485). ${ }^{41}$ P. ej. en la Rima XLI juanramoniana (una madre «estall[a] un último beso» a su hija muerta, pues «ile daría su vida en un beso, / si la vida pasarse pudiera!») (Jiménez, 2005a: 68-69).

${ }^{42}$ En la misma XLI (cuando la niña llega al cielo «besa[...]n los ángeles / sus blancas mejillas» y «la Virgen, riendo / d [a] un beso a la niña») (Jiménez, 1970: 68-69).

43 P. ej. en la LIV (las vírgenes muertas mandan desde el cielo «besos de plata» (Jiménez, 2005a: 84).

${ }^{44}$ Lo mismo sostiene Bynum en su análisis sobre la imaginación en Bécquer (1987: 130).

${ }^{45}$ Es precisa también la perspectiva de Guillén, que señala que el poeta es soñador «doblemente: porque sueña despierto, y en ese duermevela vigilante reside su función propia, y porque sueña dormido, y el mundo así representado favorece al otro, sirviéndole de referencia continua y dechado sumo» (Guillén, 1942: 4).

${ }^{46}$ La cursiva es nuestra.
} 
recuerd[a] cosas desasidas y sin sentido» (Bécquer, 1970: 166, 536-537, 442) ${ }^{47}$. El sueño es, por un lado, poético, y no basta, para el sevillano, nuestro lenguaje para describirlo; por el otro, es vago, son imágenes poco claras, al igual que los fantasmas de las visiones de los poetas. En Jiménez, cuando entra en el mundo de la forma, también se manifiesta el sueño como algo vago $^{48}$. No en vano resulta traer a colación la palabra "fantasía", claramente relacionada con la de "fantasma" y que, en las Metamorfosis ovidianas, encarnada por Phantasos, resulta ser uno de los hijos de Somnus ("sueño"), quien se aparece en sueños mediante objetos inanimados, dando forma a lo que no tiene vida (Ovidio, 1916: 164) ${ }^{49}$. Macrobio, además, en

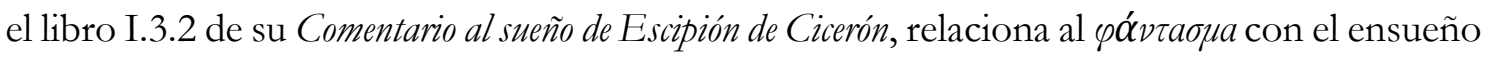
(visum; Macrobio, 1868: 473).

Ya que permite corporeizar lo que sólo es alma y que burla las reglas de la realidad despierta, ¿podría decirse que el sueño está más cerca del mundo del alma y de los muertos que del mundo del cuerpo y los vivos? ${ }^{50}$ Juan Ramón no duda en situarlo en el cielo, como en la ya mencionada Rima XIII, donde «las brisas de los países / del sueño a la tierra bajan» (Jiménez, 2005a: 31). En la Leyenda becqueriana apelada, se afirma que «los dioses descienden en él hasta los mortales», y el sueño mismo, «hijo de la tumba», dice ser «[...] eslabón invisible entre lo finito y lo infinito, entre el mundo de los hombres y el de las almas, sirviendo para bajar las potencias del cielo y elevar las de la tierra hasta que se toquen en el vacío, que es el lugar de [su] soberanía[.]» (Bécquer, 1970: 166, 155, 156). Esta razón es la que lleva al poeta a ver al sueño, tal y como afirma Pedro Díaz, como «una revelación de lo suyo», y lo siente «como una emanación directa de lo trascendental» (Pedro Díaz, 1964: 434). Viendo en él la posibilidad de, aunque por poco tiempo, sentirse liberado del cuerpo y ser casi alma, el poeta anhela habitarlo siempre, como deja ver la Rima XX de Jiménez ${ }^{51}$. La LVI exclama: «Quién pudiera dormir y soñar!»; o en la II el yo lírico quiere «[i]dormir, dormir! ¡Un sueño hondo

\footnotetext{
47 También en su introducción a las Rimas menciona «un sueño de la media noche que a la mañana no puede recordarse» (Bécquer, 1970: 73).

${ }^{48}$ Como una «bruma» en la Rima XX, «Nocturno»; una «niebla» que llega a ser «mortecina» en la XXIV; o una «penumbra» en la que se hunde el yo poético en la XXXII, «Sombras» (Jiménez, 2005a: 39, 46, 58).

${ }^{49}$ Del libro 11.642-643, en el original: «[...] Phantasos: ille in humum saxumque undamque trabemque, / quaeque vacant anima, fallaciter omnia transit». La cursiva es nuestra.

${ }^{50}$ Retomando a los griegos, así se empareja en la Teogonía 211-212 al sueño y a la muerte, ambos hijos de la noche: «Parió la Noche al maldito Moros, a la negra Ker y a Tánato [“muerte sin violencia”]; parió también a

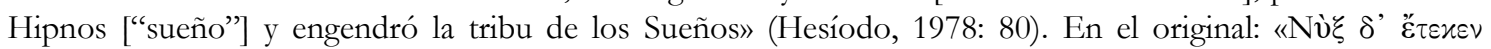

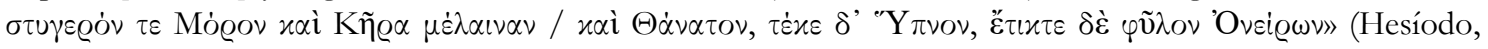
1914: 94).

${ }^{51}$ «Quién pudiera / dormitar eternamente en un ensueño, / olvidarse de la tierra / y perderse en lo infinito de los cielos!» (Jiménez, 2005a: 41).
} 
como un pozo de paz y oscuridad!» (Jiménez, 2005a: 85, 105) ${ }^{52}$. También el del sevillano, en su Rima LXXX, desearía vivir durmiendo: «jOjalá fuera un sueño / muy largo y muy profundo, / un sueño que durara hasta la muerte!...». Y es que, de modo parecido a la muerte, el sueño es capaz de quitar el dolor que aflige a los vivos durante la vigilia, pues «Triste cosa es el sueño / que llanto nos arranca», afirma la LXVIII becqueriana. El yo poético teme «quedar[se] / con [su] dolor a solas», como expresa la LII, y ansía una tranquilidad que no encuentra en la vida. El sueño le permite escapar de la suya por un tiempo, pero es sólo la muerte, con su dormir eterno, la que le ofrecerá la tranquilidad absoluta, sin el sufrimiento del vivir, como dice la LXXVI: «iQué sueño el del sepulcro, tan tranquilo!». Por este motivo, el yo lírico siente, en la XLVIII, un deseo de «dormir con ese sueño / en que acaba el soñar» (Bécquer, 1970: 124, 114, 106, 123, 105). No extraña, entonces, que los muertos a veces parezcan estar durmiendo en las Rimas de ambos poetas ${ }^{53}$.

Así como al observar a los muertos, de los que queda en el mundo de la vida sólo el cuerpo sin alma, los vivos, al dormir, descansan el suyo brevemente mientras el espíritu recorre los parajes del sueño; según Bécquer en la leyenda citada, «[c]uando la materia duerme, el espíritu vela». Allí, es el alma la que siente, y el cuerpo, si lo hace, es por alguna interrupción proveniente del mundo de la vida, como un ruido fuerte o un dolor repentino, y que suele entrometerse en el terreno onírico para terminar despertándonos. Por este motivo, se pregunta el yo poético becqueriano, en la ya tratada Rima LXXV, si

¿[s]erá verdad que cuando toca el sueño con sus dedos de rosa nuestros ojos, de la cárcel que habita huye el espíritu en vuelo presuroso?

En el soñar dormido o despierto se tergiversan tiempo y espacio. El mismo Bécquer, en su primera Carta desde mi celda, sostiene que no sabe «el tiempo que transcurrió mientras a la vez dormía y velaba»; de forma muy parecida a lo que escribe en su prólogo a La Soledad de Ferrán, cuando afirma desconocer «el tiempo que transcurrió mientras soñaba despierto» (Bécquer, 1970: 158, 121, 442, 547). El yo lírico juanramoniano, por su lado, en la Rima LXXIV, es capaz de unir, como dos cabos de un mismo hilo desatado por la vigilia, lo

\footnotetext{
52 Titulada «Ya, va, ta, ja, pla...» e incluida en el apéndice de la edición citada.

53 P. ej. en la misma LXXVI becqueriana (una muerta «parec[e] dormir en la penumbra / y que en sueños ve[...] el paraíso») (Bécquer, 1970: 123) o en las juanramonianas XXX (al niño muerto se le canta «Que no despierte el niño!») o XLI (la madre, al ver a su hija muerta, «creyóla dormida») (Jiménez, 2005a: 56, 68).
} 
que sueña el día anterior con la presente noche ${ }^{54}$. Sin embargo, el hilo se vuelve a romper a causa del mundo del cuerpo: del alba que, «suave y cruel», le da un beso y, así, lo une de nuevo con el mundo de los vivos (Jiménez, 2005a: 104). A pesar de haber podido y de poder acariciar, todas las noches, fugazmente el mundo del alma a través del sueño, el del cuerpo agarra al soñador y lo devuelve a él, al que, al fin y al cabo, pertenece. Y es que lo onírico surge inevitablemente del mundo del cuerpo y de la vida, porque son los vivos los que sueñan. Repuesto el cuerpo, o por necesidad de atención, nos llaman él y la vida para que regresemos. Como sostiene Casalduero, bajo cuyas palabras resuenan las de Aristóteles, «todo lo que duerme quiere despertar» (Casalduero, 1935: 99-100) ${ }^{55}$.

Esta misma llamada por parte del mundo corpóreo aparece en la última Rima del libro de Jiménez, la LXXIV. En ella, «un corazón dulce y fiel» logra distinguir al yo poético entre su tristeza, un corazón que viene «de allá del mundo» y trae al sufrimiento del poeta «un perfume de ilusiones, / de esperanzas y de fe». Son éstas propias de la vida y no de la muerte y los sueños, como señala él mismo en su Rima XII, «Las tardes de enero», con «la nada sin fe de los sueños» (Jiménez, 2005a: 104, 30). También Bécquer contrapone a la esperanza, «[e]sa luz santa», en la LXXXV, unos «[n]egros fantasmas» y unas «nubes sombrías» que huyen de ella ${ }^{56}$. Pero, como hemos observado en la sección 1 , el yo lírico juanramoniano no se entrega, por contraposición al becqueriano, completamente a lo perteneciente a las visiones, es decir, al mundo del alma y al del sueño, ya que, cuando es reclamado por la vida en su Rima LXXIV, no la rechaza. Volver al mundo del cuerpo y de la vida implica regresar a la lucha consigo mismo, a estar en este mundo anhelando el del alma y la muerte, y el corazón que lo llama, amigo suyo, es sabedor de esto. Y es que justamente en esto radica la solución a su lucha: aceptarla a ella y, por ende, a su condición de poeta y soñador. Y eso decide pese al dolor que causa hacerlo, especialmente a sabiendas de la muerte, ese gran misterio que llama y repele a la vez, y que puede llegar en cualquier momento ${ }^{57}$. No en vano se sitúa esto en el último poema del libro, el cual concluye el yo

\footnotetext{
${ }^{54} \mathrm{Al}$ contrario del becqueriano en la Rima LXVIII, que «[n] o s[abe] lo que h[a] soñado / en la noche pasada» (Bécquer, 1970: 114).

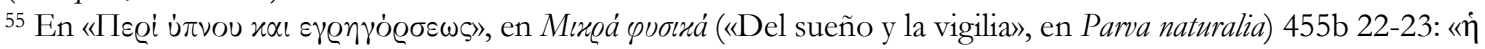
$\delta^{\prime} \dot{\varepsilon} \gamma \varrho \dot{\gamma} \gamma o \varrho o \iota \varsigma ~ \tau \dot{\varepsilon} \lambda \circ \varsigma »$ («La finalidad es despertarse») (Aristóteles, 1957: 328). La traducción del griego es nuestra. ${ }^{56}$ La edición citada no incluye esta rima, pero sí la de Afrodisio Aguado (Bécquer, 1950: 133).

${ }^{57}$ Acertadamente afirma Urrutia con sutil matiz heideggeriano que «[e]l poeta no solamente sabe que es un ser para la muerte, sino que goza con ella. El poema se escribe precisamente por ese doler que viene a ser una coincidencia de estar vivo. También de ser poeta. Por estar vivo en una situación agónica el poeta existe como tal y en esta situación desea permanecer», con lo que la melancolía se vuelve «interiorización necesaria» (Urrutia, 2010: 2136). La desdicha «como cualidad innata al pueblo español, a todos los poetas y a [Juan Ramón] en particular» es notada por Celma (1990: 378), así como p. ej. San Juan y Donate Lafitte (2016: 160-161).
} 
poético afirmando que su «vida es una lágrima / que no acaba de caer» (Jiménez, 2005a: 104). Poeta y soñador, continuará acercándose a ese misterio, pues, como bien dice Bécquer en su Rima IV, «mientras haya un misterio para el hombre, / ¡habrá poesía!» (Bécquer, 1970: 79).

\section{CONCLUSIÓN}

El misterio, entendido como aquello que se intuye, pero no se aprehende del todo y que, por lo tanto, atrae y aterra, se entromete en la poesía de Jiménez y Bécquer. Diferencian tanto las Rimas juanramonianas como las becquerianas entre lo espiritual y lo material. Al primero, por pertenecer a un espacio fuera de aquél que habitamos, a un más allá al que van las almas de los muertos, lo hemos llamado «mundo del alma y de la muerte». Contrariamente, lo corpóreo configura el lugar de los vivos y, por lo tanto, el «mundo del cuerpo y de la vida». En ambos libros, el yo poético mora en el segundo, pero sabe de la existencia del otro debido a las apariciones de ese mundo que percibe en el suyo, por un lado, mediante lo que es sólo cuerpo muerto, ya sin alma (los muertos, los moribundos y los recién fallecidos) y, por el otro, a través de los seres que parecen más alma que cuerpo (los niños y las vírgenes; los ángeles, Cristo y la Virgen María, que representan lo divino). Excepto estos tres últimos seres, los demás son parte de lo cotidiano. La percepción de la muerte en la vida, que deja a los muertos solos y tristes, provoca en el poeta un sufrimiento tan profundo que termina mezclándose con su alegría y convirtiéndose en su modo de vivir, de modo similar a Augusto Ferrán, admirado por Bécquer y Juan Ramón. Asimismo, observa el yo lírico cómo el cuerpo impide al alma elevarse a lo más alto, por lo que lo considera una cárcel de la que quisiera liberarse e ir a su mundo.

Siente también el mundo del alma y de la muerte a través de lo extraordinario que surge en el suyo, es decir, de las apariciones de seres fantasmagóricos y vagos, junto con otros elementos relativos a la muerte, como olores, ruidos y voces, a menudo provenientes de muertos o del cementerio. Todos ellos lo apelan con su «llamada» deseosa que lo lleva a sentir una atracción hacia ese otro mundo, y a la que corresponde, parecidamente a los místicos, tratando de unirse con él por el «éxtasis». Este anhelo puede llegar a hacer que el yo poético se observe a sí mismo como una figura vaga, a modo de las visiones que él ve, o incluso como un muerto. En Juan Ramón, el miedo que esa segunda imagen le provoca es resuelta con un beso, el cual, en nuestra interpretación, acentúa el deseo de unión. El beso es un 
elemento reiterado en ambos libros y que, a través de lo corpóreo, proporcionaría un breve enlace entre lo material y lo espiritual, lo vivo y lo muerto.

Existe, además, otro plano en el que se llegaría al mundo del alma y de la muerte estando todavía en el del cuerpo y de la vida, que es el sueño. En él, el alma parece salirse por unos instantes de la prisión del cuerpo e ir al más allá. No obstante, el soñador siempre es llamado de regreso por parte del mundo del cuerpo y de la vida y, por pertenecer aún a él, no puede hacer más que volver. Esto se expresa sobre todo en la última de las Rimas juanramonianas, en la cual el yo poético da muestras de aceptar y, por ende, de superar su condición dicotómica de ser parte de un mundo y anhelar otro. Así, seguirá viviendo a pesar del sufrimiento y la lucha consigo mismo, siendo consciente de su tarea de mediador entre los dos planos y llevándola a cabo a través de la poesía, que se adentra en el misterio sin poder nunca desvelarlo. O en palabras de Ferrán, en su poema CXXXVII de La Soledad:

Allá lo que nunca acaba, aquí lo que, al fin, termina: iy el hombre atado aquí abajo, mirando siempre hacia arriba! (Ferrán, 1998: 92) 


\section{BIBLIOGRAFÍA}

Alonso, Dámaso (1952): Poetas españoles contemporáneos, Madrid, Gredos.

Aristóteles (1957): On the Soul. Parva naturalia. On Breath. Translated by W. S. Hett, Cambridge, Massachusetts, Harvard University Press.

Barrenechea, Ana María (1972): «Ensayo de una Tipología de la Literatura Fantástica (A propósito de la literatura hispanoamericana)», Revista Iberoamericana, XXXVIII, 80: 391-403.

Bécquer, Gustavo Adolfo (1950): Rimas, Madrid, Afrodisio Aguado, S. A.

Bécquer, Gustavo Adolfo (1970): Obras completas, Ed. especial del centenario a cargo de los catedráticos D. a Ángeles Cardona de Gibert y D. Juan Alcina Franch, Barcelona, Editorial Bruguera.

Blanc, Mario A. (1988): «Ecos de Bécquer en la Generación del 27», Confluencia, 3, 2: 11-18.

Bynum, B. Brant (1987): The Romantic Imagination in the Works of Gustavo Adolfo Bécquer. Tesis doctoral, Ann Arbor, Michigan, University Microfilms, Inc.

Caillois, Roger (1975): Obliques. Précédé de Images, images..., París, Stock.

Carmona Tierno, Juan Manuel (2012): «La presencia de Gustavo Adolfo Bécquer en la obra de Juan Ramón Jiménez», Archivo Hispalense. Revista histórica, literaria y artística: 95, 288-290: 355-380.

Casalduero, Joaquín (1935): «Las "Rimas” de Bécquer», Cruzy raya, 32: 91-112.

Castex, Pierre-Georges (1951): Le conte fantastique en France de Nodier à Maupassant, París Corti.

Celma, María Pilar (1990): «Crítica y estética del primer Juan Ramón», en Actas del IV Congreso de Literatura Española Contemporánea. Universidad de Málaga (13, 14, 15 y 16 de noviembre de 1990). Edición dirigida por Cristóbal Cuevas García y coordinada por Enrique Baena, Barcelona, Anthropos: 375-384.

Cernuda, Luis (1957): Estudios sobre poesía española contemporánea, Madrid, Ediciones Guadarrama.

Cortina, Rodolfo José (1970): «Bécquer y la poesía mística», Revista de Estudios Hispánicos, 4, 2: $223-228$.

Cossío, José María de (1936): Notas y estudios de crítica literaria. Poesía española. Notas de asedio, Madrid, Espasa-Calpe.

Ferrán, Augusto (1998): La Soledad. Colección de cantes populares y originales, prólogo de Gustavo Adolfo Bécquer y edición de Francisco Robles, Sevilla, Signatura Ediciones. 
Guillén, Jorge (1942): «La poética de Bécquer», Revista Hispánica Moderna, 1 y 2: 1-42.

Jiménez, Juan Ramón (1990): Ideolojía (1897-1957). Metamórfosis, IV. Reconstrucción, estudio y notas de Antonio Sánchez Romeralo, Barcelona, Anthropos.

Jiménez, Juan Ramón (2005a): Obra poética. Volumen I. Prólogo de Víctor García de la Concha y edición de Francisco Javier Blasco Pascual y María Teresa Gómez Trueba, Madrid, Espasa-Calpe.

Jiménez, Juan Ramón (2005b): Obra poética. Volumen II. Prólogo de Víctor García de la Concha y edición de Francisco Javier Blasco Pascual y María Teresa Gómez Trueba, Madrid, Espasa-Calpe.

Gicovate, Bernardo (1965): «Poesía y poética de Juan Ramón Jiménez en sus primeras obras», en Anuario de Letras de México, 5: 191-201.

González Dengra, Miguel (1998): «Bécquer, precedente de la modernidad», Epos, 14: 227 238.

Harter, Hugh A. (1960): «Presencia de Bécquer en Juan Ramón Jiménez», Hispanófila, 8: 4764.

Hesíodo (1914): Hesiod, the Homeric Hymns, and Homerica. With an English translation by Hugh G. Evelyn-White, Londres y Nueva York, William Heinemann y The Macmillan Co.

Hesíodo (1978): Teogonía, introducción, traducción y notas de Aurelio Pérez Jiménez y Alfonso Martínez Díez, Madrid, Gredos.

Homero (1919): The Odyssey. With an English translation by Augustus Taber Murray, Ph. D., in two volumes, Cambridge, Massachussets, Harvard University Press y Londres, William Heinemann, Ltd.

Homero (1993): La Odisea, introducción de Manuel Fernández-Galiano y traducción de José Manuel Pabón, Madrid, Gredos.

Lanz, Juan José (2009): «“El ondear del aire”: Juan Ramón Jiménez y la poesía española de posguerra (1939-1960). Notas de aproximación», Bulletin bispanique, 111-2: 473-518, en https://journals.openedition.org/bulletinhispanique/1017 (último acceso: $13 / 10 / 2020)$.

Liddell, Henry George y Scott, Robert (1996): A Greek-English Lexicon, 9th ed. with revised supplement, Oxford, Clarendon Press, en: https://logeion.uchicago.edu/ (último acceso: 27/09/2020). 
Macrobius, Ambrosius Theodosius (1868): Macrobius, Franciscus Eyssenhardt recognovit, Leipzig, Teubner.

McKeever, Sister Mary Terence (1967): Echoes of Bécquer in Unamuno, Machado and Juan Ramón Jiménez: Tesis doctoral, Ann Arbor, Michigan, University Microfilms, Inc.

Ovidio (1916): Metamorphoses. Volume II. Books IX-XV, translated by Miller, Frank Justus and revised by Goold, George Patrick, Cambridge, Massachusetts, Harvard University Press.

Pedro Díaz, José (1964): Gustavo Adolfo Bécquer. Vida y poesía, segunda edición, corregida y aumentada, Madrid, Gredos.

Reisz, Susana (2014): «Cuando lo fantástico se infiltra en la poesía: hipótesis sobre una relación improbable», en Flavio García, Maria Cristina Batalha y Regina Michelli (org.): (Re)Visôes do Fantástico: do centro às margens; caminhos cruzados, Río de Janeiro, Dialogarts: 173-194.

Reyes Cano, Rogelio (2008): «Juan Ramón Jiménez en la Sevilla del "Fin de Siglo": Entre Bécquer y el folklorismo científico», Boletin de la Real Academia Sevillana de Buenas Letras: Minervae Baeticae, 36: 205-226.

San Juan, José Bernardo y Donate Lafitte, Irene (2016): «El poeta y su circunstancia: los comienzos poéticos de Juan Ramón Jiménez en la revista Vida Nueva (1898-1900)», Revista Chilena de Literatura, 92: 151-175.

Todorov, Tzvetan (2001): Introduction à la littérature fantastique, Paris, Éditions de Seuil.

Urrutia, Jorge (2002-2004): «Lo que va de Rimas a Rimas», Archivo de filología aragonesa, 59-60, 2: 2123-2138.

Vax, Louis (1960): L'Art et la Littérature fantastiques, París, Presses Universitaires de France.

West-Settle, Cecile (2005): «Personalized and Depersonalized Discourses: Irony and SelfConsciousness in Bécquer's Rimas», Studies in 20th \& 21st Century Literature, 29, 1: 151-167. 


\section{an}

Ue Actio nova: ReVISTA DE TEORÍA DE LA LITERATURA Y LITERATURA COMPARADA, 4: 547-570

\section{Laia Olivé Ràfols}

Doctoranda en Filología Española en la Universidad de Valladolid con una tesis sobre Juan Ramón Jiménez. Máster en Literatura Comparada por la Universidad de Heidelberg, Alemania. Ha publicado el poemario Lucía es pasado (2019) en la Editorial Verbum y ha colaborado, entre otros, con la revista El Juglar (julio de 2020).

Contact information: laia.olive@outlook.com 